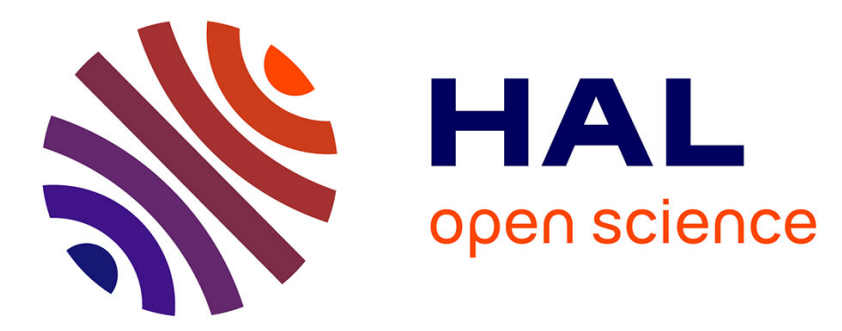

\title{
Rational Design of PDZ Domain Inhibitors: Discovery of Small Organic Compounds Targeting PDZ Domains
}

\author{
Laurent Hoffer, Philippe Roche, Xavier Morelli
}

\section{To cite this version:}

Laurent Hoffer, Philippe Roche, Xavier Morelli. Rational Design of PDZ Domain Inhibitors: Discovery of Small Organic Compounds Targeting PDZ Domains. Jean-Paul Borg. PDZ Mediated Interactions. Methods and Protocols, 2256, Springer US, pp.277-289, 2021, Methods in Molecular Biology, 978-10716-1165-4. 10.1007/978-1-0716-1166-1_16 . hal-03380205

\section{HAL Id: hal-03380205 https://hal.science/hal-03380205}

Submitted on 15 Oct 2021

HAL is a multi-disciplinary open access archive for the deposit and dissemination of scientific research documents, whether they are published or not. The documents may come from teaching and research institutions in France or abroad, or from public or private research centers.
L'archive ouverte pluridisciplinaire HAL, est destinée au dépôt et à la diffusion de documents scientifiques de niveau recherche, publiés ou non, émanant des établissements d'enseignement et de recherche français ou étrangers, des laboratoires publics ou privés. 
archives-ouvertes

\title{
Rational Design of PDZ Domain Inhibitors: Discovery of Small Organic Compounds Targeting PDZ Domains
}

\author{
Laurent Hoffer, Philippe Roche, Xavier Morelli
}

\section{To cite this version:}

Laurent Hoffer, Philippe Roche, Xavier Morelli. Rational Design of PDZ Domain Inhibitors: Discovery of Small Organic Compounds Targeting PDZ Domains. PDZ Mediated Interactions, 2256, Springer US, pp.277-289, 2021, Methods in Molecular Biology, 10.1007/978-1-0716-1166-1_16 . hal-03380205

\section{HAL Id: hal-03380205 \\ https://hal.archives-ouvertes.fr/hal-03380205}

Submitted on 15 Oct 2021

HAL is a multi-disciplinary open access archive for the deposit and dissemination of scientific research documents, whether they are published or not. The documents may come from teaching and research institutions in France or abroad, or from public or private research centers.
L'archive ouverte pluridisciplinaire HAL, est destinée au dépôt et à la diffusion de documents scientifiques de niveau recherche, publiés ou non, émanant des établissements d'enseignement et de recherche français ou étrangers, des laboratoires publics ou privés. 


\section{Rational design of PDZ domain inhibitors: Discovery of small organic compounds targeting PDZ domains}

\section{Laurent Hoffer*, Philippe Roche \& Xavier Morelli*}

Centre de Recherche en Cancérologie de Marseille (CRCM), Aix-Marseille Université, Inserm, CNRS and Institut Paoli-Calmettes, Marseille, F-13009, France.

* Correspondence should be addressed to Xavier Morelli (xavier.morelli@inserm.fr) and/or Laurent Hoffer (laurent.hoffer@inserm.fr).

Running head: Rational design of PDZ domain inhibitors 
Running head: Rational design of PDZ domain inhibitors

\begin{abstract}
PDZ domains, which belong to protein-protein interaction networks, are critical for regulating important biological processes such as scaffolding, trafficking and signaling cascades. Interfering with PDZ-mediated interactions could affect these numerous biological processes. Thus, PDZ domains have emerged as promising targets to decipher biological phenomena and potentially treat cancer and neurological diseases. In this minireview, we focus on the discovery and design of small molecule inhibitors to modulate PDZ domains. These compounds interfere with endogenous protein partners from the PDZ domain by binding at the proteinprotein interface. While peptides or peptidomimetic ligands were described to modulate PDZ domains, the focus of this review is on small organic compounds.
\end{abstract}

Keywords: PDZ domain, PDZ inhibitors, rational design, screening, molecular modeling. 


\section{Introduction}

Post-synaptic density protein 95/Drosophila disc large tumor suppressor/Zonula occludens 1 (PDZ) proteins are a family of proteins that contain at least one PDZ domain. The binding of protein partners to PDZ domains mediates various processes, such as the formation of protein networks, the immobilization of these proteins in the correct cellular compartment and the ability of promoting scaffolding, trafficking and signaling events [1-4].

The PDZ domain is a common structural domain of approximately 90 amino acids found in signaling proteins of many organisms. The global structure is conserved and usually consists of 5-6 $\beta$-strands and $2 \alpha$-helixes. In general, PDZ domains have a shallow binding site located between one $\beta$-strand and one $\alpha$-helix that recognizes the C-terminus (terminal carboxylate and last residues) of their protein partners (Fig. 1).

C-terminal residues from a protein partner form an additional antiparallel $\beta$-sheet by interacting with residues of the PDZ domain through hydrogen bonds with backbone atoms. In addition, the C-terminal carboxylate group from the protein partner interacts with the backbone of a conserved loop in the PDZ domain through a canonically conserved hydrogen bond network [2].

More precisely, PDZ domains typically require a hydrophobic residue at the Cterminal position of their protein partner, and this residue fits into a small hydrophobic pocket near the carboxylate binding loop. Typical hydrophobic residues are valine, leucine and isoleucine. By convention, P0 refers to the C-terminal residue of the peptide, and P-n refers to the nth amino acid of the peptide starting from its Cterminal end. PDZ domains have been classified according to their specificity for PDZ ligands. Consensus sequences were built to define these groups [5]. Briefly, "class 1" PDZ domains recognize C-terminal sequences with either a serine or 
threonine at the -2 position. Similarly, "class 2" PDZ domains bind to C-terminal sequences with a large hydrophobic or aromatic residue at the -2 position. Finally, the consensus sequence recognized by "class 3" PDZ domains includes a negatively charged residue at the -2 position. Other positions, such as -1 and -3 , have fewer constraints regarding the nature of the residue sidechain. Due to these small constraints, many peptides can bind different PDZ domains [6], so achieving high specificity is expected to be challenging.

It is also known that some PDZ domains are able to bind to lipids. For instance, syntenin1 can interact with phosphatidylinositol phosphates with an affinity in the micromolar range [7].

\section{PDZ domains as potential drug targets}

PDZ domains, which are critical for regulating important biological processes, have emerged as promising targets to treat cancer and neurological diseases [8-10,1,11-13]. Early inhibitors of PDZ domains consisted of using short amino acid sequences representing the key C-terminal residues from endogenous partners. Later, modified peptides, including thioketone and non-natural residues, were reported as biological tools to study PDZ domains $[14,15]$. Bivalent peptides were also shown to exhibit high affinity for PDZ domains by simultaneously interacting with multiple PDZ domains from the same protein [16]. In addition, TAT-derived bivalent peptides, which contain cell permeability tags, were also developed as efficient probes [16]. Despite their potential high affinities, peptides may suffer from protein degradation by proteases and cell permeability issues. Thus, an appealing alternative strategy is to develop small molecule inhibitors for oral administration that bypass these issues. However, targeting PDZ domains may be very challenging because this requires tackling the general problem of protein-protein interactions (PPIs). It has been shown 
that modulating PPIs using small organic compounds is difficult due to the nature of the interface [17]. In general, such interfaces are large and flat with several small adjacent subpockets and are not expected to be easily druggable [18,19]. Several screening studies concluded, as expected, that PDZ domains are mainly undruggable targets to be modulated by small organic molecules and even fragments [20,21]. Indeed, the screening of fragment-like compounds is considered a powerful tool to assess the druggability of a given target [21]. These disappointing results are not truly surprising from a structural point of view; the nature of the PDZ domain binding pocket appears to be shallow with only a few putative interacting hotspots. Despite the fact that PDZ domains are poorly suited for the development of small organic probes, different studies were reported in which inhibitor compounds were discovered. The ultimate goals are to develop probes to decipher PDZ-related biology and potential therapeutic drugs that target PDZ domains. However, most compounds exhibited inhibition in the 10 micromolar range, despite intensive structure-activity relationship (SAR) studies where close analogs are synthesized and tested. These compounds were discovered using either a screening-based strategy, molecular modeling experiment or a combination of both approaches. Currently reported PDZ inhibitors are quickly reviewed below, and their 2D structures are depicted in Fig. 2.

Fujii et al. reported the first cell-permeable irreversible inhibitor targeting a PDZ domain (MAGI3-PDZ2) in 2003 [22]. The designed compound was a potent inhibitor of the interaction between PTEN and MAGI3, presenting an original covalent mode of action. Docking studies using the DOCK tool [23] suggested that the indole-3carbinol moiety could mimic the hydrophobic end of the partner while preorienting chemical groups toward crucial residues from the MAGI3-PDZ2 domain. It should be noted that this compound was covalently bound to the MAGI3-PDZ2 domain through the histidine residue H372. Starting from this covalent binder [22], Fujii et al. 
reported a reversible version of their indole-containing inhibitor for the same PDZ domain [24]. As previously described, DOCK software guided the rational design of new compounds to mimic the four C-terminal residues of the protein partner. This ligand was able to displace the reference peptide probe in a concentration-dependent manner. However, the affinity of the compound for MAGI3-PDZ was relatively weak, as a competition was observed with concentrations in the $100 \mu \mathrm{M}$ range. In another study, the same compound was able to disrupt the interaction between the Frizzed-7 Wnt receptor and the PDZ domain of Dishevelled [25], leading to the downregulation of the canonical Wnt signaling and suppression of tumor cell growth. According to this study, the compound was among the first nonpeptide inhibitors to show therapeutic efficacy through the disruption of a PDZ PPI. Finally, this indole core was also used to target the PDZ domain of NHERF1 [26]. Similar to the study from Fujii et al., the DOCK tool was employed to suggest putative inhibitors designed around the indole moiety [23]. In contrast to previous work, an additional carboxylate group was incorporated at the end of the flexible aliphatic sidechain of the compound to mimic the aspartic residue from the reference partner. In 2013, Vogrig et al. published small compounds able to disrupt the PSD-95PDZ1/5-HT2A receptor interaction leading to an antihyperalgesic activity [27]. These inhibitors were discovered using a structure-based approach that combined molecular modeling and NMR. A series of indole analogues were synthesized on the basis of docking studies using AutoDock Vina software [28]. Their ability to bind to the first PDZ domain (PDZ1) of the PSD-95 protein was then assessed using NMR experiments. The best compound exhibited a moderate $\mathrm{IC}_{50}$ value of $190 \mu \mathrm{M}$.

PDZ inhibitors, which were able to disrupt the PSD-95-PDZ2/GluN2B PPI, were discovered using a rational "click chemistry" strategy [29]. The aim was to mimic the TAV/SAV tripeptide PSD-95 ligand using triazole-containing compounds that were 
easily synthesized from reactive azide and alkyne moieties. The triazole heterocycle was chosen because it was previously reported as a potential amide bioisostere while being more rigid and not recognized by protein peptidases. One triazole-containing compound inhibited the PSD-95-PDZ2/GluN2B interaction with an affinity similar to that measured for the SAV tripeptide. ITC experiments concluded that the compound had a low affinity for the PSD-95-PDZ2 domain $\left(K_{d}\right.$ value in the $600 \mu \mathrm{M}$ range). Finally, molecular docking simulations using the Glide tool [30] suggested that the triazole-containing compound interacts with the PDZ2 domain in a similar way as the TAV tripeptide.

In 2010, Thorsen et al. reported an organic compound (FSC231) able to bind to the PDZ domain from PICK1 [9]. The inhibitor was identified using a fluorescent polarization assay by screening approximately 44,000 compounds. This inhibitor exhibited an affinity similar to that measured for peptide ligands (C-terminal end from endogenous protein partners) in the $10 \mu \mathrm{M}$ range. The AutoDock tool [31-33] was employed to predict the binding mode of the compound within the PDZ binding site. Molecular dynamics simulations were performed with the AMBER package [34] to refine the predicted binding mode. During subsequent SAR studies around FSC231, Bach et al. managed to slightly improve the $K_{i}$ value by replacing chlorine atom in the meta position with a trifluoromethyl group [35].

More potent chemical inhibitors targeting the PDZ domain from PICK1 were recently published [36]. These inhibitors were able to modulate the amyloid betamediated synaptic dysfunction by interfering with the PICK1-PDZ/GluA2 PPI. Such potent compounds in the submicromolar range are interesting for the biological study of memory mechanisms and may be used as potential treatments for neurodegenerative disorders. An integrated strategy involving high-throughput screening, structure-based drug design, and biochemical and cellular assays was used to discover potent small molecule PICK1-PDZ inhibitors. This structure-based 
strategy relied on determining the protein-ligand structure using X-ray crystallography, followed by intensive SAR studies to increase the potency of the series. The X-ray crystallography experiments were more difficult than expected because conventional methods and conditions failed to produce any cocrystal structures. A new approach called the "lock and chop" method was developed to tackle this issue [37]. Analysis of the X-ray crystal structure of the complex (PDB ID: 6AR4) revealed that the chemical compound was located in the expected binding pocket and was able to tightly interact with a phenylalanine sidechain that was not targeted by the endogenous peptide. The most potent compound from the series exhibited an approximately 200-fold better potency than that from the C-terminal of the GluA2 partner. Selectivities with respect to other reference PDZ domains were also measured for this series of compounds. This remarkable integrated study reported the highest affinity for small molecule inhibitors of the PDZ domain known to date, with an $\mathrm{IC}_{50}$ value of $70 \mathrm{nM}$. The X-ray crystal structure, deposited in the protein databank (PDB ID: 6AR4), corresponds to a compound from the series with an $\mathrm{IC}_{50}$ value of $600 \mathrm{nM}$. Unfortunately, these compounds were unable to cross the blood brain barrier, preventing any potential use as drug candidates. However, they can still be used as chemical probes in biology studies due to their high potency.

NMR spectroscopy-based screening allowed the detection of weakly binding inhibitors for the PDZ domain from AF6, which is an essential component of cell junctions [38]. A dissociation constant $\left(K_{d}\right)$ value of $100 \mu \mathrm{M}$, which is in the same range as last residues from the endogenous EphB2 partner, was obtained with one analog designed around the rhodanine core. More intensive SAR studies around the same core were published several years later [39]. The design of new compounds was guided by molecular modeling using the 3D structure of the PDZ domain of interest. The new derivatives were again evaluated using an NMR-based approach. The best compound, a mixture of diastereoisomers, exhibited a $5 \mu \mathrm{M}$ affinity for AF6- 
PDZ. Molecular docking using the MOE package (http:/ / www.chemcomp.com) was performed to identify the most likely active stereoisomer from the diastereoisomer mixture.

Dishevelled (Dvl) is an essential protein in the Wnt signaling pathway that relies on its PDZ domain for transduction of downstream signals [11]. Interestingly, a known sulindac drug was shown to inhibit the canonical Wnt signaling pathway by binding to the PDZ domain of Dvl [40]. NMR experiments enabled the determination of the "sulindac / PDZ domain" complex and concluded that sulindac is located within the peptide binding pocket of the PDZ domain. Finally, a $K_{i}$ value of $10 \mu \mathrm{M}$ was measured for sulindac in a competitive assay with a reference peptide. Additional chemical compounds, which bind to the Dvl-PDZ domain in the low micromolar range affinity, were discovered using a protocol involving both molecular modeling and NMR spectroscopy [11]. In silico experiments employed a structure-based pharmacophore search using the Unity module from Sybyl [41] to identify small organic compounds that could mimic the binding mode of the Dapper protein partner within the PDZ domain. Then, the FlexX docking tool [42] was used to confirm the ability of selected compounds to act as potential PDZ domain binders. NMR spectroscopy was used as an experimental method to validate (or not) the selected compounds. A benzoic acid molecule, which displayed the most significant chemical shift perturbations, exhibited a $10 \mu \mathrm{M} \mathrm{K} \mathrm{K}_{\mathrm{d}}$ value. Finally, in vivo studies confirmed its ability to reduce the growth rate of prostate cancer cell lines. A similar strategy was used in another study to target the PSD95-PDZ domain [43]. The binding of the best identified fragment (quinoline-2,7-dicarboxylic acid) was confirmed using NMR experiments.

Another study focused on the Dvl protein identified small molecules that perturb the Dvl-PDZ/CXXC5 PPI [44]. Inhibition of this interaction may have potential interest 
in bone anabolic osteoporosis therapy by enhancing osteoblast differentiation [44]. More than 50 analogs were synthesized to explore the chemical space around the hit while also trying to increase the microsomal stability and optimize the physicochemical properties. Binding modes of representative compounds from the series were predicted using molecular docking with DOCKER from the Discovery Studio package [45]. The best compound, which exhibited a Dvl-PDZ binding affinity of $8 \mu \mathrm{M}$, successfully rescued bone loss in an ovariectomized mouse model. These authors also reported additional studies that focused on the same Dvl protein and employed various computational approaches to identify other PDZ inhibitors [46,47]. For example, in the work reported by Ma et al. [47], X-ray crystal structures of DvlPDZ bound to an organic compound and snapshots from molecular dynamics simulations of the Dvl-PDZ/ peptide complex guided the creation of pharmacophore models. These models combined with a virtual screening of a large chemical library allowed the identification of compounds that could mimic the binding mode of reference molecules. Fluorescence spectroscopy and NMR experiments confirmed the binding of several compounds at the Dvl-PDZ/CXXC5 interface, and the best compound had a $\mathrm{K}_{\mathrm{d}}$ value of $22 \mu \mathrm{M}$.

Using a combination of NMR, quantitative structure-activity relationship (QSAR) and structure-based pharmacophore filtering, Shan et al. identified and optimized inhibitors for the Dvl-PDZ domain [48]. This series of compounds essentially consists of merging a benzoic acid moiety with two protein residues. The best compound from the series exhibited a $\mathrm{K}_{\mathrm{i}}$ value of $1.5 \mu \mathrm{M}$ in the fluorescence polarization assay. Potential binding modes were predicted using the Glide docking tool [30] and matched those from endogenous partners.

Hori et al. reported new inhibitors for the Dvl-PDZ domain using the "NMR/Docking Performance Index" (NMR-DPI) protocol, which relies on both NMR and molecular docking experiments [49]. Several reference inhibitors were 
investigated with GOLD as the docking engine [50,51] to select the best scoring scheme using different scoring functions (ChemScore, GoldScore and ChemPLP) and with and without consensus scoring. The best scoring protocol was then employed for virtual screening with a focused library (approximately $5 \mathrm{~K}$ compounds). In total, 13 compounds were selected to be experimentally tested, and several of them showed partial proliferation inhibition activity against a triple-negative breast cancer cell line.

Saupe et al. reported in 2011 a study about the Shank3-PDZ domain [10]. The ChemBioNet library was first screened using a fluorescence polarization assay, and one natural product-like scaffold (cyclopentyl-tetrahydroquinoline-carboxylates) emerged as a PDZ inhibitor. SAR studies around this core were performed to optimize its potency. The best compound analog exhibited a $K_{i}$ value in the $10 \mu \mathrm{M}$ range, and the binding of the compound within the PDZ domain was confirmed by NMR experiments. Then, X-ray crystallography studies were used to determine the structure of Shank3-PDZ/inhibitor complex (PDB ID: 3O5N) and to confirm its ability to mimic the C-terminal end of the protein partner.

Kegelman et al. disclosed one chemical inhibitor, which targets the first PDZ domain of syntenin (Synt-PDZ1), using an integrated strategy involving an NMR-based screening of fragment-like compounds, SAR studies and molecular modeling [13]. More precisely, approximately $5 \mathrm{~K}$ fragments were initially evaluated using an NMRbased screening. Two nonoverlapping fragments were identified, and a structurebased linking strategy was employed to merge them. Ultimately, a combination of molecular docking studies using GOLD software $[50,51]$ and SAR studies produced a fused compound that exhibited a dissociation constant $\left(\mathrm{K}_{\mathrm{d}}\right)$ of $21 \mu \mathrm{M}$ for Synt-PDZ1. From a biological point of view, glioblastoma multiform (GBM) is one of the most aggressive cancers and is associated with short survival times and poor response to radiotherapy because of its invasive properties. It has been shown that syntenin is 
overexpressed in this kind of cancer. Both genetic and pharmacological strategies to modulate syntenin reduced invasion gains in GBM cells following radiation. Finally, intraperitoneal administration of the developed inhibitor improved the survival of brain tumor-bearing mice.

Finally, we also reported an integrated study by combining proteomic and genetic techniques with structural biochemistry and molecular modeling, providing a detailed discovery of small compounds targeting the PDZ domain from GRASP55 [52]. The impacts on germ cell Golgi remodeling and spermatogenesis after administration of the compound were also studied. First, X-ray crystal structures of GRASP55 in complex with JAM-C or JAM-B were obtained and revealed that GRASP55 underwent conformational changes with respect to its free conformation, with the latter being more open. An in silico protocol involving high-throughput docking and pharmacophore filtering was performed to identify potential GRASP55PDZ inhibitors. A library of 200,000 compounds dedicated to PPIs was used, and these compounds were docked into the binding site of the closed GRASP55-PDZ conformation using the Surflex docking tool [53], thereby producing millions of poses. Pharmacophore filtering, using Unity package from Sybyl [41], was then used to extract compounds that could mimic the canonical binding mode of the JAM peptides. Approximately 50 molecules were purchased and tested experimentally using homogeneous time-resolved fluorescence (HTRF), leading to the identification of a chemical compound that inhibited the GRASP55-PDZ/JAMs interaction with an $\mathrm{IC}_{50}$ of $8 \mu \mathrm{M}$. Unfortunately, despite intensive efforts, an X-ray crystal structure for this compound in complex with GRASP55-PDZ was not obtained. In the end, the biological relevance of the GRASP55-PDZ/JAM-C interaction in spermatogenesis was validated using both genetic ablation of the encoding GRASP55 gene and disruption of this PPI using a small organic compound. Treatment of mice with the inhibitor induced premature release of spermatids and germ cell loss, and thus, this 
inhibitor has potential to be used as male contraception.

\section{Conclusion}

There is growing interest in the development of compounds able to modulate PPIs, as they control a large number of physiological events and are involved in many diseases [54,55]. However, PPIs are considered challenging targets for the development of chemical probes or drugs. PDZ domains belong to PPI networks, and therefore are essentially considered poor druggable targets. This is confirmed by the screening of large compound libraries in which no high affinity hits were yet identified [20]. Despite this classification as being poor druggable targets, dozens of studies have reported small organic compounds able to disrupt PPIs between PDZ domains and their endogenous protein partners. Various strategies involving a combination of experimental screening, biophysical methods, molecular modeling and organic chemistry were employed to tackle the development of PDZ inhibitors. However, most nonpeptide compounds reported thus far exhibited moderate affinity in the $10 \mu \mathrm{M}$ range. Promisingly, several integrative studies recently reported submicromolar compounds, enabling future opportunities for the use of PDZ inhibitors as important tools to decipher biological processes and as potential therapeutics to treat some cancers and neurological diseases.

\section{References}

1. Wang NX, Lee HJ, Zheng JJ (2008) Therapeutic use of PDZ protein-protein interaction antagonism. Drug News Perspect 21 (3):137-141

2. Chi CN, Bach A, Strømgaard K, Gianni S, Jemth P (2012) Ligand binding by PDZ domains. Biofactors 38 (5):338-348. doi:10.1002/biof.1031

3. Dev KK (2004) Making protein interactions druggable: targeting PDZ domains. Nat Rev Drug Discov 3 (12):1047-1056. doi:10.1038/nrd1578

4. Grillo-Bosch D, Choquet D, Sainlos M (2013) Inhibition of PDZ domain-mediated interactions. Drug Discov Today Technol 10 (4):e531-540. doi:10.1016/j.ddtec.2012.10.003 
5. Songyang Z, Fanning AS, Fu C, Xu J, Marfatia SM, Chishti AH, Crompton A, Chan AC, Anderson JM, Cantley LC (1997) Recognition of unique carboxyl-terminal motifs by distinct PDZ domains. Science 275 (5296):73-77. doi:10.1126/science.275.5296.73

6. Wiedemann U, Boisguerin P, Leben R, Leitner D, Krause G, Moelling K, Volkmer-Engert R, Oschkinat $H$ (2004) Quantification of PDZ domain specificity, prediction of ligand affinity and rational design of super-binding peptides. J Mol Biol 343 (3):703-718. doi:10.1016/j.jmb.2004.08.064

7. Wawrzyniak AM, Vermeiren E, Zimmermann P, Ivarsson Y (2012) Extensions of PSD95/discs large/ZO-1 (PDZ) domains influence lipid binding and membrane targeting of syntenin-1. FEBS Lett 586 (10):1445-1451. doi:10.1016/j.febslet.2012.04.024

8. Aarts M, Liu Y, Liu L, Besshoh S, Arundine M, Gurd JW, Wang YT, Salter MW, Tymianski M (2002) Treatment of ischemic brain damage by perturbing NMDA receptor- PSD-95 protein interactions. Science 298 (5594):846-850. doi:10.1126/science.1072873

9. Thorsen TS, Madsen KL, Rebola N, Rathje M, Anggono V, Bach A, Moreira IS, Stuhr-Hansen $\mathrm{N}$, Dyhring $T$, Peters $D$, Beuming T, Huganir R, Weinstein H, Mulle C, Strømgaard K, Rønn LC, Gether $U$ (2010) Identification of a small-molecule inhibitor of the PICK1 PDZ domain that inhibits hippocampal LTP and LTD. Proc Natl Acad Sci U S A 107 (1):413-418. doi:10.1073/pnas.0902225107

10. Saupe J, Roske Y, Schillinger C, Kamdem N, Radetzki S, Diehl A, Oschkinat H, Krause G, Heinemann U, Rademann J (2011) Discovery, structure-activity relationship studies, and crystal structure of nonpeptide inhibitors bound to the Shank3 PDZ domain. ChemMedChem 6 (8):1411-1422. doi:10.1002/cmdc.201100094

11. Grandy D, Shan J, Zhang X, Rao S, Akunuru S, Li H, Zhang Y, Alpatov I, Zhang XA, Lang RA, Shi DL, Zheng JJ (2009) Discovery and characterization of a small molecule inhibitor of the PDZ domain of dishevelled. J Biol Chem 284 (24):16256-16263. doi:10.1074/jbc.M109.009647

12. Patra CR, Rupasinghe CN, Dutta SK, Bhattacharya S, Wang E, Spaller MR, Mukhopadhyay D (2012) Chemically modified peptides targeting the PDZ domain of GIPC as a therapeutic approach for cancer. ACS Chem Biol 7 (4):770-779. doi:10.1021/cb200536r

13. Kegelman TP, Wu B, Das SK, Talukdar S, Beckta JM, Hu B, Emdad L, Valerie K, Sarkar D, Furnari FB, Cavenee WK, Wei J, Purves A, De SK, Pellecchia M, Fisher PB (2017) Inhibition of radiation-induced glioblastoma invasion by genetic and pharmacological targeting of MDA9/Syntenin. Proc Natl Acad Sci U S A 114 (2):370-375. doi:10.1073/pnas.1616100114

14. Bach A, Chi CN, Olsen TB, Pedersen SW, Røder MU, Pang GF, Clausen RP, Jemth P, Strømgaard K (2008) Modified peptides as potent inhibitors of the postsynaptic density95/N-methyl-D-aspartate receptor interaction. J Med Chem 51 (20):6450-6459. doi:10.1021/jm800836w

15. Bach A, Eildal JN, Stuhr-Hansen N, Deeskamp R, Gottschalk M, Pedersen SW, Kristensen AS, Strømgaard K (2011) Cell-permeable and plasma-stable peptidomimetic inhibitors of the postsynaptic density-95/N-methyl-D-aspartate receptor interaction. J Med Chem 54 (5):1333-1346. doi:10.1021/jm1013924

16. Bach A, Clausen BH, Møller M, Vestergaard B, Chi CN, Round A, Sørensen PL, Nissen KB, Kastrup JS, Gajhede M, Jemth P, Kristensen AS, Lundström P, Lambertsen KL, Strømgaard K (2012) A high-affinity, dimeric inhibitor of PSD-95 bivalently interacts with PDZ1-2 and protects against ischemic brain damage. Proc Natl Acad Sci U S A 109 (9):3317-3322. doi:10.1073/pnas.1113761109

17. Wells JA, McClendon CL (2007) Reaching for high-hanging fruit in drug discovery at 
protein-protein interfaces. Nature 450 (7172):1001-1009. doi:10.1038/nature06526

18. Morelli X, Bourgeas R, Roche $P$ (2011) Chemical and structural lessons from recent successes in protein-protein interaction inhibition (2P2I). Curr Opin Chem Biol 15 (4):475481. doi: 410.1016/j.cbpa.2011.1005.1024. Epub 2011 Jun 1022.

19. Bourgeas R, Basse MJ, Morelli X, Roche P (2010) Atomic analysis of protein-protein interfaces with known inhibitors: the 2P2I database. PLoS One 5 (3):e9598. doi:10.1371/journal.pone.0009598

20. Chen X, Longgood JC, Michnoff C, Wei S, Frantz DE, Bezprozvanny L (2007) Highthroughput screen for small molecule inhibitors of Mint1-PDZ domains. Assay Drug Dev Technol 5 (6):769-783. doi:10.1089/adt.2007.092

21. Hajduk P, Huth J, Fesik S (2005) Druggability indices for protein targets derived from NMR-based screening data. J Med Chem 48 (7):2518-2525. doi:10.1021/jm049131r

22. Fujii N, Haresco JJ, Novak KA, Stokoe D, Kuntz ID, Guy RK (2003) A selective irreversible inhibitor targeting a PDZ protein interaction domain. J Am Chem Soc 125 (40):12074-12075. doi:10.1021/ja035540l

23. Ewing TJ, Makino S, Skillman GA, Kuntz ID (2001) DOCK 4.0: Search strategies for automated molecular docking of flexible molecule databases. Journal of Computer-Aided Molecular Design 15 (5):411-428

24. Fujii N, Haresco JJ, Novak KA, Gage RM, Pedemonte N, Stokoe D, Kuntz ID, Guy RK (2007) Rational design of a nonpeptide general chemical scaffold for reversible inhibition of PDZ domain interactions. Bioorg Med Chem Lett 17 (2):549-552. doi:10.1016/j.bmcl.2006.10.006 25. Fujii N, You L, Xu Z, Uematsu K, Shan J, He B, Mikami I, Edmondson LR, Neale G, Zheng J, Guy RK, Jablons DM (2007) An antagonist of dishevelled protein-protein interaction suppresses beta-catenin-dependent tumor cell growth. Cancer Res 67 (2):573-579. doi:10.1158/0008-5472.CAN-06-2726

26. Mayasundari A, Ferreira AM, He L, Mahindroo N, Bashford D, Fujii N (2008) Rational design of the first small-molecule antagonists of NHERF1/EBP50 PDZ domains. Bioorg Med Chem Lett 18 (3):942-945. doi:10.1016/j.bmcl.2007.12.038

27. Vogrig A, Dorr L, Bouzidi N, Boucherle B, Wattiez AS, Cassier E, Vallon G, Ripoche I, Abrunhosa-Thomas I, Marin P, Nauton L, Thery V, Courteix C, Lian LY, Ducki S (2013) Structure-based design of PDZ ligands as inhibitors of 5-HT(2A) receptor/PSD-95 PDZ1 domain interaction possessing anti-hyperalgesic activity. ACS Chem Biol 8 (10):2209-2216. doi:10.1021/cb400308u

28. Trott O, Olson AJ (2010) AutoDock Vina: improving the speed and accuracy of docking with a new scoring function, efficient optimization, and multithreading. J Comput Chem 31 (2):455-461. doi:10.1002/jcc.21334

29. Bach A, Pedersen TB, Strømgaard K (2016) Design and synthesis of triazole-based peptidomimetics of a PSD-95 PDZ domain inhibitor. MedChemComm 7 (3):531-536. doi:10.1039/C5MD00445D

30. Friesner RA, Banks JL, Murphy RB, Halgren TA, Klicic JJ, Mainz DT, Repasky MP, Knoll EH, Shelley M, Perry JK, Shaw DE, Francis P, Shenkin PS (2004) Glide: A new approach for rapid, accurate docking and scoring. 1. Method and assessment of docking accuracy. Journal of Medicinal Chemistry 47 (7):1739-1749. doi:10.1021/jm0306430

31. Morris GM, Goodsell DS, Halliday RS, Huey R, Hart WE, Belew RK, Olson AJ (1998) Automated docking using a Lamarckian genetic algorithm and an empirical binding free energy function. Journal of Computational Chemistry 19 (14):1639-1662

32. Goodsell DS, Morris GM, Olson AJ (1996) Automated docking of flexible ligands: 
Applications of AutoDock. Journal of Molecular Recognition 9 (1):1-5

33. Morris GM, Huey R, Lindstrom W, Sanner MF, Belew RK, Goodsell DS, Olson AJ (2009) AutoDock4 and AutoDockTools4: Automated docking with selective receptor flexibility. J Comput Chem 30 (16):2785-2791. doi:10.1002/jcc.21256

34. Case DA, Cheatham TE, Darden T, Gohlke H, Luo R, Merz KM, Onufriev A, Simmerling C, Wang B, Woods RJ (2005) The Amber biomolecular simulation programs. J Comput Chem 26 (16):1668-1688. doi:10.1002/jcc.20290

35. Bach A, Stuhr-Hansen N, Thorsen TS, Bork N, Moreira IS, Frydenvang K, Padrah S, Christensen SB, Madsen KL, Weinstein H, Gether U, Strømgaard K (2010) Structure-activity relationships of a small-molecule inhibitor of the PDZ domain of PICK1. Org Biomol Chem 8 (19):4281-4288. doi:10.1039/c0ob00025f

36. Lin EYS, Silvian LF, Marcotte DJ, Banos CC, Jow F, Chan TR, Arduini RM, Qian F, Baker DP, Bergeron C, Hession CA, Huganir RL, Borenstein CF, Enyedy I, Zou J, Rohde E, Wittmann M, Kumaravel G, Rhodes KJ, Scannevin RH, Dunah AW, Guckian KM (2018) Potent PDZ-Domain PICK1 Inhibitors that Modulate Amyloid Beta-Mediated Synaptic Dysfunction. Sci Rep 8 (1):13438. doi:10.1038/s41598-018-31680-3

37. Marcotte DJ, Hus JC, Banos CC, Wildes C, Arduini R, Bergeron C, Hession CA, Baker DP, Lin E, Guckian KM, Dunah AW, Silvian LF (2018) Lock and chop: A novel method for the generation of a PICK1 PDZ domain and piperidine-based inhibitor co-crystal structure. Protein Sci 27 (3):672-680. doi:10.1002/pro.3361

38. Joshi M, Vargas C, Boisguerin P, Diehl A, Krause G, Schmieder P, Moelling K, Hagen V, Schade M, Oschkinat H (2006) Discovery of low-molecular-weight ligands for the AF6 PDZ domain. Angew Chem Int Ed Engl 45 (23):3790-3795. doi:10.1002/anie.200503965

39. Vargas C, Radziwill G, Krause G, Diehl A, Keller S, Kamdem N, Czekelius C, Kreuchwig A, Schmieder P, Doyle D, Moelling K, Hagen V, Schade M, Oschkinat H (2014) Small-molecule inhibitors of AF6 PDZ-mediated protein-protein interactions. ChemMedChem 9 (7):14581462. doi:10.1002/cmdc. 201300553

40. Lee HJ, Wang NX, Shi DL, Zheng JJ (2009) Sulindac inhibits canonical Wnt signaling by blocking the PDZ domain of the protein Dishevelled. Angew Chem Int Ed Engl 48 (35):64486452. doi:10.1002/anie.200902981

41. Tripos Sybyl. St. Louis, MO

42. Kramer B, Rarey M, Lengauer T (1999) Evaluation of the FLEXX incremental construction algorithm for protein-ligand docking. Proteins 37 (2):228-241. doi:10.1002/(SICI)10970134(19991101)37:2<228::AID-PROT8>3.0.CO;2-8 [pii]

43. Bouzidi N, Deokar H, Vogrig A, Boucherle B, Ripoche I, Abrunhosa-Thomas I, Dorr L, Wattiez AS, Lian LY, Marin P, Courteix C, Ducki S (2013) Identification of PDZ ligands by docking-based virtual screening for the development of novel analgesic agents. Bioorg Med Chem Lett 23 (9):2624-2627. doi:10.1016/j.bmcl.2013.02.100

44. Kim HY, Choi S, Yoon JH, Lim HJ, Lee H, Choi J, Ro EJ, Heo JN, Lee W, No KT, Choi KY (2016) Small molecule inhibitors of the Dishevelled-CXXC5 interaction are new drug candidates for bone anabolic osteoporosis therapy. EMBO Mol Med 8 (4):375-387. doi:10.15252/emmm.201505714

45. AccelrysSoftware Discovery Studio. San Diego, CA

46. Choi J, Ma S, Kim HY, Yun JH, Heo JN, Lee W, Choi KY, No KT (2016) Identification of small-molecule compounds targeting the dishevelled PDZ domain by virtual screening and binding studies. Bioorg Med Chem 24 (15):3259-3266. doi:10.1016/j.bmc.2016.03.026

47. Ma S, Choi J, Jin X, Kim HY, Yun JH, Lee W, Choi KY, No KT (2018) Discovery of a small- 
molecule inhibitor of DvI-CXXC5 interaction by computational approaches. J Comput Aided Mol Des 32 (5):643-655. doi:10.1007/s10822-018-0118-x

48. Shan J, Zhang X, Bao J, Cassell R, Zheng JJ (2012) Synthesis of potent dishevelled PDZ domain inhibitors guided by virtual screening and NMR studies. Chem Biol Drug Des 79 (4):376-383. doi:10.1111/j.1747-0285.2011.01295.x

49. Hori K, Ajioka K, Goda N, Shindo A, Takagishi M, Tenno T, Hiroaki H (2018) Discovery of Potent Disheveled/Dvl Inhibitors Using Virtual Screening Optimized With NMR-Based Docking Performance Index. Front Pharmacol 9:983. doi:10.3389/fphar.2018.00983

50. Jones G, Willett P, Glen R, Leach A, Taylor R (1997) Development and validation of a genetic algorithm for flexible docking. J Mol Biol 267 (3):727-748. doi:S0022-2836(96)908979 [pii]

10.1006/jmbi.1996.0897

51. Verdonk ML, Cole JC, Hartshorn MJ, Murray CW, Taylor RD (2003) Improved proteinligand docking using GOLD. Proteins-Structure Function and Genetics 52 (4):609-623. doi:10.1002/prot.10465

52. Cartier-Michaud A, Bailly AL, Betzi S, Shi X, Lissitzky JC, Zarubica A, Sergé A, Roche $P$, Lugari A, Hamon V, Bardin F, Derviaux C, Lembo F, Audebert S, Marchetto S, Durand B, Borg JP, Shi N, Morelli X, Aurrand-Lions M (2017) Genetic, structural, and chemical insights into the dual function of GRASP55 in germ cell Golgi remodeling and JAM-C polarized localization during spermatogenesis. PLoS Genet 13 (6):e1006803. doi:10.1371/journal.pgen.1006803

53. Jain AN (2003) Surflex: Fully automatic flexible molecular docking using a molecular similarity-based search engine. Journal of Medicinal Chemistry 46 (4):499-511. doi:10.1021/jm.020406h

54. Petta I, Lievens S, Libert C, Tavernier J, De Bosscher K (2016) Modulation of ProteinProtein Interactions for the Development of Novel Therapeutics. Molecular Therapy 24 (4):707-718. doi:10.1038/mt.2015.214

55. Ivanov AA, Revennaugh B, Rusnak L, Gonzalez-Pecchi V, Mo X, Johns MA, Du Y, Cooper LAD, Moreno CS, Khuri FR, Fu H (2018) The OncoPPi Portal: an integrative resource to explore and prioritize protein-protein interactions for cancer target discovery. Bioinformatics 34 (7):1183-1191. doi:10.1093/bioinformatics/btx743

\section{Figure Captions}

Figure 1: 3D crystallographic structure of the second PDZ domain of Syntenin (Synt-PDZ-2). (A) General fold of Synt-PDZ-2. The protein is shown as cartoon representation and the carboxylate binding loop is highlighted. (B) Structure of "Synt-PDZ-2/ peptide" complex (PDB ID: 1OBY). The PDZ domain and peptide (Cterminus from Syndecan-4: TNEFYA) are displayed as surface and sticks representation, respectively. The shallow hydrophobic subpocket, recognizing the terminal hydrophobic tail from the peptide partner, is highlighted. (C) Detailed view 
of "Synt-PDZ-2/peptide" complex. The PDZ domain and its peptide partner are displayed as cartoon and sticks representation, respectively. Direct hydrogen bonds between both entities are represented as black dashed lines. Syntenin residues involved in hydrogen bonds with the peptide partner are colored in pink. (D) Twodimensional interaction diagram between PDZ-2 domain of Syntenin and TNEFYA peptide partner. 3D structures were generated using Pymol (www.pymol.org) and MOE (https:// www.chemcomp.com) was used to create the 2D interaction diagram.

Figure 2: 2D structures and references of small organic inhibitors discussed in the minireview. 


\section{Rational design of PDZ domain inhibitors: Discovery of small organic compounds targeting PDZ domains}

Laurent Hoffer*, Philippe Roche \& Xavier Morelli*

Centre de Recherche en Cancérologie de Marseille (CRCM), Aix-Marseille Université, Inserm, CNRS and Institut Paoli-Calmettes, Marseille, F-13009, France.

* Correspondence should be addressed to Xavier Morelli (xavier.morelli@inserm.fr) and/or Laurent Hoffer (laurent.hoffer@inserm.fr).

Running head : Rational design of PDZ domain inhibitors 

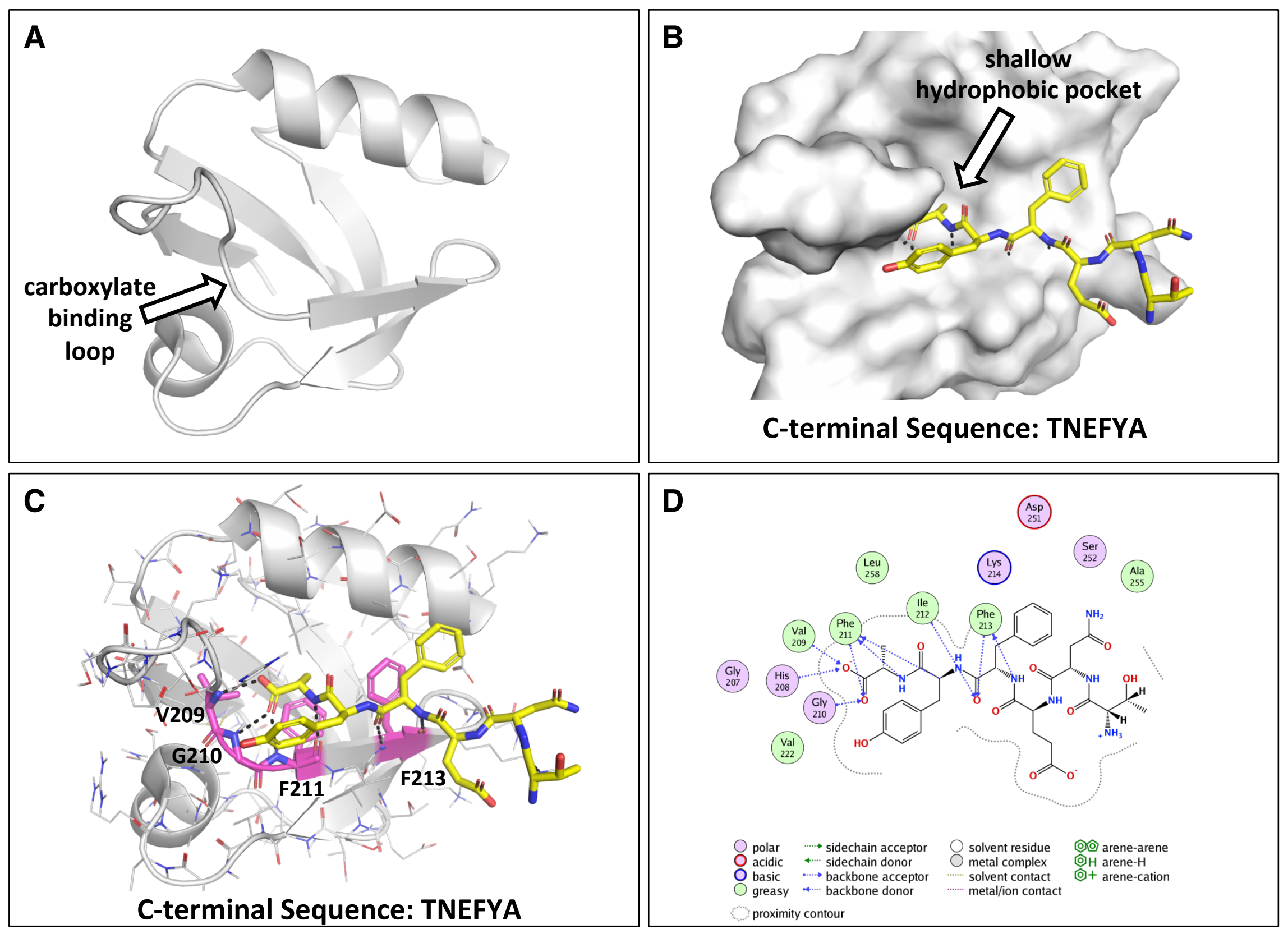
